\title{
AFROTHISMIA GESNERIOIDES, ANOTHER NEW SPECIES OF AFROTHISMIA (BURMANNIACEAE) FROM TROPICAL AFRICA
}

\author{
H. MAAS-VAN DE KAMER \\ Nationaal Herbarium Nederland, Utrecht University branch, \\ Heidelberglaan 2, 3584 CS Utrecht, The Netherlands \\ e-mail: hmaas-vandekamer@bio.uu.nl
}

SUMMARY

A new species of Afrothismia, A. gesnerioides H. Maas is described and illustrated. A key to the genus Afrothismia is included.

Key words: Afrothismia, Burmanniaceae, key, taxonomy.

\section{INTRODUCTION}

In 1905 Engler described the first species of Afrothismia as "Thismia winkleri, eine neue afrikanische Burmanniacee" from Cameroon. In the same article he created section Afrothismia of the genus Thismia to accommodate his new species. In 1906 Schlechter described the genus Afrothismia (Engl.) Schltr., and at the same time added the second species of Afrothismia, A. pachyantha. He found both species growing, as mycotrophs often do, at the same locality in Cameroon (Moliwe). It was not until 1988, that Jill Cowley, in the Flora of Tropical East Africa, described the third species of Afrothismia from Tanzania, A. insignis. She also described a new variety of $A$. winkleri, var. budongensis, from Uganda and cited $A$. winkleri var. winkleri from Cameroon and Nigeria. Summarizing there are now 6 different taxa known in Afrothismia: 4 species and 2 varieties. All are known from limited areas, some only from the type locality.

Quite unexpectedly there have been collected recently more new species which are in the process of being described and published. One of those specimens collected in Cameroon by A.J. de Winter was brought to my attention. When identifying the specimen my conclusion was that it had to be a new species characterized by flowers with a geniculate perianth tube with unequal, relatively small tepals, and a vertically orientated throat (opening sidewards). It differs from A. pachyantha by the shape of the perianth tube, which is geniculate in the new species, i.e. composed of an upper and a lower part which are orientated in different directions and separated by a constriction, in A. pachyantha the perianth tube is subglobose, not geniculate. 


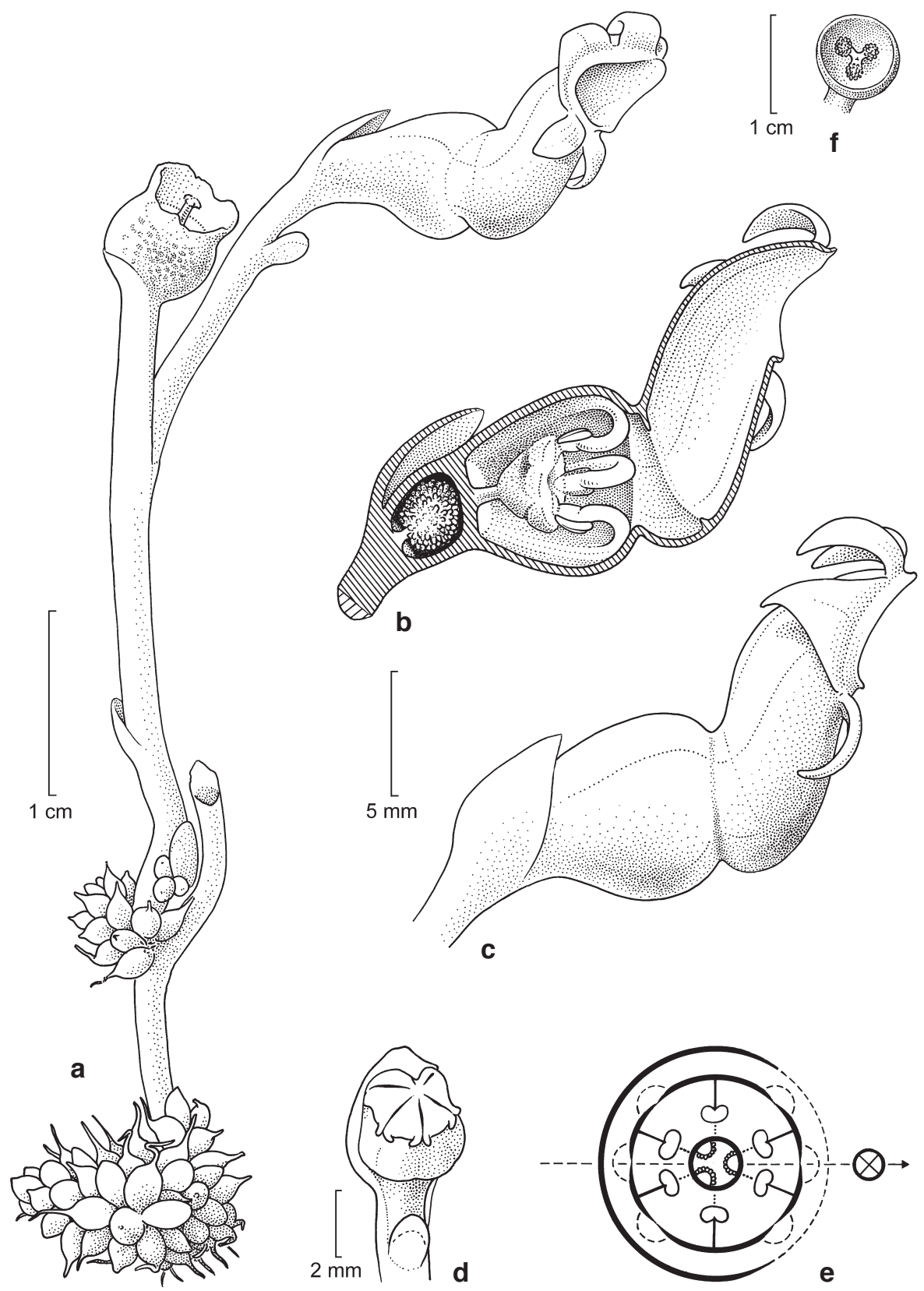

Fig. 1. Afrothismia gesnerioides H. Maas. a. Habit; b. longitudinally opened flower; c. flower; d. floral bud; e. floral diagram; f. old fruit (a-d,f: De Winter 91; e: after a drawing by Sue Williams made of a living plant in Cameroon 1995). 


\section{Afrothismia gesnerioides $\mathrm{H}$. Maas, spec. nov. - Fig. 1}

Afrothismia gesnerioides $\mathrm{H}$. Maas spec. nov. a speciebus ceteris Afrothismiae tubo perianthii geniculato tepalibus inaequalibus pro rata minoris praeterea fauce tubi perianthii verticali differt. - Typus: A.J. de Winter 91, only spirit, 24 April 1996 (holo WAG 0075095, iso U), Cameroon, South Province, Nyangong, $2050 \mathrm{~m}$ on transect $* 2 / 4$, riverine forest along stream, marshy spot, alt. $600 \mathrm{~m}$, fl. and fr.

Achlorophyllous, whitish brown, mycotrophic herb, 4.5-6 $\mathrm{cm}$ tall. Rhizomes (subterranean stems) provided with several subglobose clusters of root tubercles. Each cluster in the axil of a bract, 5-10 mm diam., composed of 20-35 tubercles; tubercles ovoid, 2-3 mm long, 1-2 mm diam., bearing an apical rootlet to 5-6 $\mathrm{mm}$ long. Leaves (bract-like but without flower in the axil) 1 per stem, (broadly) ovate-triangular, 3-5 by $2-4 \mathrm{~mm}$, apex acute to rounded, base attenuate. Flowering stems white, 4.5-6 cm long, 1-2 mm diameter. Inflorescence terminal, 2- or 3-flowered, sympodially branched, internodes 5-15 mm. Bract one per flower, elliptic to broadly ovate or obovate, (1.5-)4-12 by (1-)4-7 mm, apex rounded, sometimes shortly apiculate, base attenuate to stem clasping. Flowers purplish, strongly zygomorphic, 17-21 mm long (measured from base of ovary to centre of throat). Tepals 6 , basally connate into a tube, 6 longitudinal veins running from base of tube to top of tepals, tube geniculate, lower part of tube urceolate, more or less 6-ribbed, directed horizontally, 6-7 mm diam. at widest point, $3-4.5 \mathrm{~mm}$ at base, and $5-6 \mathrm{~mm}$ at apex, above this urceolate part the tube constricted, upper part of tube subcylindrical, directed vertically, 6-7 mm diam. at widest point, 5-6 $\mathrm{mm}$ diam. at base, and 4-7 $\mathrm{mm}$ at apex, internal flange slightly irregular, c. $0.5 \mathrm{~mm}$ wide running all around the inside of the tube at $2-4.5 \mathrm{~mm}$ above the constriction at c. $45^{\circ}$ from the vertical i.e. at the same place where the perianth tube is bent at right angles, throat vertical, 4-7 mm diam., free part of tepals valvate, later on reflexed, basally hastate when young, the upper and lower pair triangular, 4 by $2-2.5$ $\mathrm{mm}$, the middle pair broadly triangular, 4 by $4 \mathrm{~mm}$. Stamens 6 , epitepalous, free from the perianth tube just below the constriction, filament c. $1.5 \mathrm{~mm}$ long, pendent, thecae ellipsoid, 1 by $0.5 \mathrm{~mm}$, essentially introrse, but facing the perianth tube and opening longitudinally towards the wall of the perianth tube, apical connective c. $1 \mathrm{~mm}$ long, firmly adnate to the stigmatic surface. Ovary obconical, $4 \mathrm{~mm}$ high, 3-4.5 $\mathrm{mm}$ diam., 1-celled, with 3 parietal placentas which are fused into one column at the base and free above, style cylindrical, $1-1.5 \mathrm{~mm}$, stigmatic head obconical, apically $2-3 \mathrm{~mm}$ wide, densely minutely papillate, the basal part saucer-shaped, c. $0.5 \mathrm{~mm}$ high, c. $2 \mathrm{~mm}$ diam., the upper part composed of 3 erect, stipitate lobes, stipes c. $0.5 \mathrm{~mm}$ high, c. $0.5 \mathrm{~mm}$ diam., the lobes transversely bilobed, c. $2 \mathrm{~mm}$ high, c. $0.5 \mathrm{~mm}$ diameter. Fruit obconical to subglobose, 5-6 $\mathrm{mm}$ high, 5-6 $\mathrm{mm}$ diam., perianth caducous leaving only a small rim (1 mm high) on the fruit; seeds narrowly ellipsoid, c. $1 \mathrm{~mm}$ long.

Distribution - Cameroon, in undisturbed rain forest.

Notes -1 . This species is so far only known from Nyangong in South Province.

2. Etymology: Afrothismia gesnerioides is named after the shape of its zygomorphic and geniculate flower, as encountered in many neotropical Gesneriaceae, like in the genus Gasteranthus. 


\section{KEY TO THE GENUS AFROTHISMIA}

1a. Perianth tube geniculate: upper and lower part of tube separated by a constriction

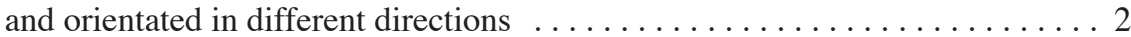

b. Perianth tube not geniculate, not divided in 2 different parts, subglobose, throat vertical (opening sidewards). - Cameroon

A. pachyantha

2a. Tepals unequal, triangular, reflexed; throat vertical (opening sidewards). - Cameroon $\ldots \ldots \ldots \ldots \ldots \ldots \ldots \ldots \ldots \ldots \ldots \ldots \ldots \ldots \ldots \ldots \ldots \ldots \ldots$ gesnerioides

b. Tepals equal, filiform, patent; throat horizontal (opening upwards) . . . . . 3

3a. Tepals $0.5-1.5 \mathrm{~cm}$ long; perianth tube $0.5-1 \mathrm{~cm}$ long, internal flange running all around inner side of tube (c. $1 \mathrm{~mm}$ wide). - Cameroon, Nigeria, Uganda . . . . . .

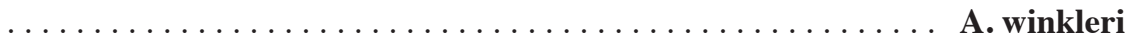

b. Tepals $1.2-3.6 \mathrm{~cm}$ long; perianth tube $1.7-2 \mathrm{~cm}$ long, internal flange not completely surrounding inner side of tube $(3-6 \mathrm{~mm}$ wide $)$. - Tanzania . . . . . A. insignis

\section{ACKOWLEDGEMENTS}

Thanks are due to Dr. Jan Wieringa, taxonomist of the Wageningen University branch of the Nationaal Herbarium Nederland for providing me with the material collected by a colleague of his in Cameroon. Special thanks to Hendrik Rypkema, the artist of our Institute, who made the illustration with ultimate care. Last but not least I owe many thanks to Thassilo Franke and Sue Williams for their drawings which were put at my disposal, and which proved to be invaluable to unravel some of the problems in the taxonomy of Afrothismia.

\section{REFERENCES}

Cowley, E.J. 1988. Burmanniaceae. In: R.M. Polhill, Flora of Tropical East Africa: 6-8. Balkema, Rotterdam.

Engler, A. 1905. Thismia winkleri Engl., eine neue afrikanische Burmanniacee. Bot. Jahrb. Syst. 38: 89-91.

Schlechter, R. 1906. Burmanniaceae africanae 29. Bot. Jahrb. Syst. 38: 138-140. 